\title{
Isolation, Characterization and Performance of Autochthonous Spray Dried Lactic Acid Bacteria in Maize Micro and Bucket-Silos
}

OPEN ACCESS

Edited by:

Javier Carballo,

University of Vigo, Spain

Reviewed by:

Giuseppe Spano,

University of Foggia, Italy

Anna Reale,

Istituto di Scienza dell'Alimentazione

(ISA), Italy

${ }^{*}$ Correspondence:

Patricia Burns

pburns@fbcb.unl.edu.ar;

burns_patricia@hotmail.com

Specialty section: This article was submitted to

Food Microbiology,

a section of the journal

Frontiers in Microbiology

Received: 06 September 2018 Accepted: 06 November 2018

Published: 28 November 2018

Citation:

Burns $P$, Borgo MF, Binetti A

Puntillo M, Bergamini C, Páez $R$,

Mazzoni R, Reinheimer J and

Vinderola G (2018) Isolation,

Characterization and Performance

of Autochthonous Spray Dried Lactic

Acid Bacteria in Maize Micro

and Bucket-Silos.

Front. Microbiol. 9:2861.

doi: 10.3389/fmicb.2018.02861

\section{Patricia Burns ${ }^{1 *}$, María F. Borgo ${ }^{1}$, Ana Binetti ${ }^{1}$, Melisa Puntillo ${ }^{1}$, Carina Bergamini', Roxana Páez ${ }^{2}$, Rodolfo Mazzoni ${ }^{3}$, Jorge Reinheimer ${ }^{1}$ and Gabriel Vinderola'}

${ }^{1}$ Instituto de Lactología Industrial (INLAIN, UNL-CONICET), Facultad de Ingeniería Química, Universidad Nacional del Litoral, Santa Fe, Argentina, ${ }^{2}$ Instituto Nacional de Tecnología Agropecuaria (INTA EEA Rafaela), Rafaela, Argentina, ${ }^{3}$ Fragaria SRL, Villa Cañas, Argentina

The aim of this study was to isolate, identify and characterize lactic acid bacteria $(\llcorner A B)$ from spontaneously fermented maize silage, and evaluate their performance as spray-dried (SD) cultures to enhance the fermentation and the aerobic stability of maize micro-silos. Eleven strains of LAB were characterized for growth kinetics, the capability to grow in vegetable-based medium (VBM), production of organic acids and the ability to tolerate heat-stress. Three strains (Lactobacillus plantarum Ls71, Pediococcus acidilactici Ls72, and Lactobacillus buchneri Ls141) were selected and further characterized for the ability to grow as single strain or in co-culture in MRS and VMB medium, to survive at freeze and spray-drying process, for their performance as SD bacteria in micro-silos and for the aerobic stability in bucket silos. L. buchneri Ls141 showed the highest growth capability in VBM and produced the highest amount of acetic acid, while $L$. plantarum Ls71 produced the highest amounts of lactic acid. $P$. acidilactici Ls72 was the most heat-resistant strain, with a reduction of $0.2 \log _{10}$ $\mathrm{CFU} / \mathrm{mL}\left(15 \mathrm{~min}\right.$ at $55^{\circ} \mathrm{C}$ ). The three strains satisfactorily tolerated both spray and freeze-drying. After 4 days of fermentation, all the samples reached a $\mathrm{pH}$ value of about 3.7-3.8. A significantly lower cell load of filamentous fungi and yeasts $\left(<3 \log _{10}\right.$ $\mathrm{CFU} / \mathrm{g}$ ) and a higher concentration of total LAB (> $8.7 \log _{10} \mathrm{CFU} / \mathrm{g}$ ) was observed after 30 days of fermentation. A greater amount of acetic acid, crude protein, ash and ammonia nitrogen/total nitrogen was detected in inoculated silages. A significant reduction of filamentous fungi and yeasts was also observed in inoculated bucket silos after $50 \mathrm{~d}$ of fermentation. The aerobic stability was significantly improved in inoculated silage since the temperature remained stable after 16 days (384 h). On the contrary, an increase of $5^{\circ} \mathrm{C}$ was observed in control samples after 1 day. The selected strains have the potential to be produced as SD silage inoculant as they were able to accelerate the fermentation process, to control filamentous fungi and yeasts, to improve some nutritional and chemical parameters of silage and to improve aerobic stability.

Keywords: maize, silage, lactic acid bacteria, spray-drying, inoculant, aerobic stability 


\section{INTRODUCTION}

Ensiling is a crop preservation method based onnatural lactic acid fermentation under anaerobic conditions. Epiphytic LAB plays a major role in silage fermentation; however, their count is usually variable in silage crops (Lin et al., 1992). The use of different chemical and biological additives is suggested to improved silage quality (Ávila et al., 2014). According to the composition 6 categories of additives can be mentioned: homofermentative $\mathrm{LAB}$, obligate heterofermentative $\mathrm{LAB}$, combination inoculants (containing obligate heterofermentative + homofermentative LAB), other inoculants (non LAB), chemicals, and enzymes (Muck et al., 2018). Microbial inoculants composed of strains of facultatively homofermentative LAB such as L. plantarum, L. casei, various Pediococcus species and Enterococcus faecium are the older and most common commercially available additives. In the late 1990s, a new class of inoculants appeared in the market, based on obligate heterofermentative LAB such as L. buchneri. This bacterium grows slowly even after the active fermentation period is finished, producing acetic acid that can inhibit the growth of yeasts and filamentous fungi, improving aerobic stability (Kleinschmit and Kung, 2006; Ávila et al., 2014; Muck et al., 2018).

Nowadays, there is a growing interest in the use of microbiological additives to improve the fermentation process, thus resulting in better quality silage. In Argentina, most of the inoculants are provided by foreign companies as freezedried cultures. Spray drying is an interesting and promising low-cost alternative to freeze-drying and allows the continuous production of large amounts of dried cells within short time periods. During this process, bacterial cultures are exposed to different stresses due to the quite harsh conditions of temperature required for product dehydration, which can cause a partial thermal inactivation of cells. It was observed that the success of its application is highly strain specific (Paéz et al., 2012, 2013).

In this context, the aim of this study was to isolate and characterize LAB from spontaneously fermented maize silage, formulate a spray-dried (SD) inoculant and assess its performance to improve the fermentation profile and the aerobic stability of maize micro-silos.

\section{MATERIALS AND METHODS}

\section{Samples and Isolation of LAB}

Spontaneously fermented maize silages samples (Zea mays) were obtained from two local farms (from Esperanza and Recreo cities, located at 35 and $20 \mathrm{~km}$, respectively, from Santa Fe, Argentina) at the beginning (time $=0$ ) and after 7, 14, and 21 days of silage-making. Samples were taken immediately to the lab for microbiological analysis. Each sample (10 g) was mixed with $90 \mathrm{~mL}$ of peptone water $(0.1 \% \mathrm{w} / \mathrm{v}$, Britannia, Buenos Aires, Argentina), homogenized (stomacher, 120 s, low speed) serially diluted and surface-plated on MRS (de Man, Rogose, and Sharpe), MRS bile, MRS-LP, and M17 agar (Biokar, Beauvais, France) (Vinderola and Reinheimer, 1999). Plates were incubated aerobically (or anaerobically, MRS-LP) at $34^{\circ} \mathrm{C}$ for $72 \mathrm{~h}$
(Oxoid, Basingstoke, United Kingdom). Twenty two colonies presenting typical LAB morphology (examined by phase-contrast microscopy, $1000 \times$ ) were isolated and purified for Gram-staining reaction, mobility, catalase activity and gas production (in MRS broth with Dürham tube). Presumptive LAB isolates were frozen stored in MRS broth added with $20 \% \mathrm{v} / \mathrm{v}$ glycerol (Ciccarelli, Buenos Aires, Argentina) at $-20^{\circ} \mathrm{C}$ and $-70^{\circ} \mathrm{C}$.

\section{Identification of Isolates}

Total DNA of isolates was obtained from overnight cultures $(20 \mathrm{~h})$ by using the GenElute ${ }^{\mathrm{TM}}$ Bacterial Genomic DNA kit (Sigma, St. Louis, MO, United States) according to the manufacturer's instructions. Purified DNA samples were stored at $-20^{\circ} \mathrm{C}$ until use. The identity of isolates was analyzed by amplifying (primers pA: AGA GTT TGA TCC TGG CTC AG, and pH: AAG GAG GTG ATC CAG CCG CA), sequencing and comparing a 1500 bp fragment within their 16S rRNA gene (Edwards et al., 1989). All PCR reactions were performed using $2 \mu \mathrm{L}$ of diluted (1:50) DNA as template, $2.5 \mathrm{U}$ Taq DNA polymerase (GE Healthcare, Little Chalfont, United Kingdom), $200 \mu \mathrm{M}$ dNTPs (GE Healthcare) and $100 \mathrm{nM}$ each primer (Sigma-Genosys, The Woodlands, TX, United States) in a final volume of $50 \mu \mathrm{L}$. Amplifications were performed in a GeneAmp PCR System (Applied Biosystems, Foster City, CA, United States) under the following conditions: $3 \mathrm{~min}$ at $94^{\circ} \mathrm{C}, 36$ cycles of $1 \mathrm{~min}$ at $94^{\circ} \mathrm{C}, 2 \mathrm{~min}$ at $51^{\circ} \mathrm{C}$ and $2 \mathrm{~min}$ at $72^{\circ} \mathrm{C}$, and a final step of $7 \mathrm{~min}$ at $72^{\circ} \mathrm{C}$. The PCR products were separated on $0.8 \%(\mathrm{w} / \mathrm{v})$ agarose gels in TBE buffer, stained with GelRed (Biotium, Hayward, CA, United States) and visualized under UV light (Sambrook and Russell, 2001). Amplicons were purified with MicroSpin Columns (GE Healthcare) and their nucleotide sequences were determined by primer extension at the DNA Sequencing Service of Macrogen (Seoul, Korea). The identity of isolates was checked by nucleotide-nucleotide BLAST of the NCBI database ${ }^{1}$.

\section{Growth Kinetics}

MRS broth was inoculated (1\% v/v) with an overnight culture of each strain [(previously washed twice with PBS (phosphate buffer solution)] and incubated at $30,34,37$, and $43^{\circ} \mathrm{C}$ in a 96-well microplate (Thermo Scientific Multiskan FC Microplate Photometer). Optical density $\left(\mathrm{OD}_{570} \mathrm{~nm}\right)$ was measured every 30 min during $24 \mathrm{~h}$. The OD data were modeled with Statistica software (Version 8.0; StatSoft., Tulsa, OK, United States), by using the Gompertz equation as modified by Zwietering et al. (1990), in order to evaluate the cell growth parameters [ $\left(\mu_{\max }\right.$ : maximum specific growth rate as variation of $\mathrm{OD}_{570 \mathrm{~nm} / \mathrm{h}} ; \lambda$ : lag time in hours)].

At the same time, MRS broth $(10 \mathrm{~mL})$ was inoculated $(1 \%$ $\mathrm{v} / \mathrm{v}$ ) and incubated for $24 \mathrm{~h}$ (at 30, 34, 37, and $43^{\circ} \mathrm{C}$ ). Colony counts (MRS agar, $34^{\circ} \mathrm{C}, 72 \mathrm{~h}$, aerobiosis) were carried out at the beginning and after $24 \mathrm{~h}$ of incubation. Results are expressed as ( $\Delta \log _{10} \mathrm{CFU} / \mathrm{mL}$ ), where $\Delta$ is the difference between cell counts after $24 \mathrm{~h}$ and the initial count.

\footnotetext{
${ }^{1}$ https://blast.ncbi.nlm.nih.gov/Blast.cgi
} 


\section{Growth Kinetics in Vegetable-Based Medium and Determination of Organic Acids and Carbohydrates \\ Vegetable-Based Medium (VBM)}

A fresh (non-fermented) sample of chopped maize obtained before silage fermentation was mixed (1:10) with distilled water, homogenized (stomacher, $120 \mathrm{~s}$, low power), filtered (QUANTY JP41 Faixa Preta, Londrina, PR, Brazil) and centrifuged $(5000 \times g$, $10 \mathrm{~min}, 5^{\circ} \mathrm{C}$ ). The $\mathrm{pH}$ of the supernatant was adjusted to 6.5 with $1 \mathrm{M} \mathrm{NaOH}$, aliquoted and stored at $-20^{\circ} \mathrm{C}$. Before each experiment, the medium was autoclaved $\left(121^{\circ} \mathrm{C}, 15 \mathrm{~min}\right)$.

\section{Cell Growth in VBM and Determination of Organic Acids and Carbohydrates by HPLC}

An overnight fresh culture of each strain (previously washed twice with PBS) was inoculated $(1 \% \mathrm{v} / \mathrm{v})$ in VBM and anaerobically incubated at $34^{\circ} \mathrm{C}$, during $72 \mathrm{~h}$. Colony counts were performed at $0,24,48$, and $72 \mathrm{~h}$ in MRS agar. Results are expressed as $\left(\Delta \log _{10} \mathrm{CFU} / \mathrm{mL}\right)$, where $\Delta$ is the difference between cell counts after 24,48 , and $72 \mathrm{~h}$ and the initial count. $\mathrm{pH}$ was measured after $72 \mathrm{~h}$ of culture (Orion 3 Star, Thermo Scientific, Beverly, MA, United States) and the supernatant was recovered by centrifugation $\left(8000 \times g, 15 \mathrm{~min}, 5^{\circ} \mathrm{C}\right)$. The quantification of organic acids (lactic, acetic, and propionic) and carbohydrates (glucose and fructose) was performed by HPLC according to Vénica et al. (2014). Chromatographic separation was carried out isocratically at $65^{\circ} \mathrm{C}$ with a mobile phase of $10 \mathrm{mM} \mathrm{H}_{2} \mathrm{SO}_{4}$ at a flow rate of $0.6 \mathrm{~mL} / \mathrm{min}$ on an Aminex HPX-87H column $(300 \times 7.8 \mathrm{~mm})$ equipped with a cation $\mathrm{H}+$ microguard cartridge (Bio-Rad Laboratories, United States). The supernatant of cultures after centrifugation was diluted 1:3 with $10 \mathrm{mM} \mathrm{H}_{2} \mathrm{SO}_{4}$, filtered through $0.45 \mu \mathrm{m}$ membrane (Millex, Millipore, Brazil) and injected into the chromatograph, using a loop of $60 \mu \mathrm{L}$. HPLC equipment consisted of a quaternary pump, an on-line degasser, a column oven, a UV-visible detector (all Series 200) and a refractive index detector thermostatized at $35^{\circ} \mathrm{C}$ (Series Flexar) (Perkin Elmer, United States). The UV detector was set at $210 \mathrm{~nm}$ for the detection of organic acids, while the IR detector setting at $35^{\circ} \mathrm{C}$ was used for the analyses of carbohydrates. Data were collected and processed on a computer with the software Chromera ${ }^{\circledR}$ (Perkin Elmer).

\section{Tolerance to Heat Stress}

Strains were grown overnight in MRS broth, centrifuged $\left(8000 \times g, 15 \mathrm{~min}, 5^{\circ} \mathrm{C}\right)$, washed twice in PBS $(\mathrm{pH} 7.2)$ and resuspended in $5 \mathrm{~mL}$ of the same buffer. Cell suspensions were aliquoted $(1 \mathrm{~mL})$ and placed into a water bath at $55^{\circ} \mathrm{C}$ with mild stirring. At time $=0$ and after 5 and $15 \mathrm{~min}$, samples were removed and placed in a cold-water bath. Colony counts (MRS agar, $34^{\circ} \mathrm{C}, 72 \mathrm{~h}$, aerobiosis) were carried out to determine the tolerance of strains to heat stress.

\section{Microbial Growth as Single or Co-culture in MRS and VBM}

Fresh cultures of the selected strains (Lactobacillus plantarum Ls71, Pediococcus acidilactici Ls72 and Lactobacillus buchneri
Ls141, see discussion section) in MRS broth were centrifuged $\left(5000 \times g, 20 \mathrm{~min}, 8^{\circ} \mathrm{C}\right)$, washed twice with sterile PBS and resuspended in the same buffer to obtain a cell suspension of $c . a$. $2 \times 10^{8} \mathrm{CFU} / \mathrm{mL}$. MRS broth or VBM was inoculated $(1 \% \mathrm{v} / \mathrm{v})$ with the strains as pure cultures (positive control of growth) or in co-culture (2 or 3 strains together) and anaerobically incubated at $34^{\circ} \mathrm{C}$ during $24 \mathrm{~h}$. Cell counts (MRS agar, $34^{\circ} \mathrm{C}, 72 \mathrm{~h}$, aerobiosis) were performed at the beginning and after $24 \mathrm{~h}$. It was previously checked that strains could be differentiated (MRS agar surface plating) according to their colony morphology.

\section{Resistance to Spray and Freeze-Drying}

Overnight cultures in MRS broth of the selected strains (L. plantarum Ls71, P. acidilactici Ls72, and L. buchneri Ls141) were centrifuged $\left(5000 \times g, 20 \mathrm{~min}, 8^{\circ} \mathrm{C}\right)$, washed twice with PBS ( $\mathrm{pH} 7.2$ ) and resuspended in $20 \%(\mathrm{w} / \mathrm{v})$ (1:1) maltodextrin (Gelfix, Buenos Aires, Argentina)-whey protein concentrate (WPC80) (Arla Foods, Porteña, Córdoba, Argentina).

Cell suspensions (prepared as described above) were SD in a laboratory scale spray dryer (Buchi mini spray dryer model B290, Flawil, Switzerland). An inlet air temperature of 138$145^{\circ} \mathrm{C}$, an outlet temperature of $81-83^{\circ} \mathrm{C}$ and a flux of $600 \mathrm{~L} / \mathrm{h}$ were used. Cell suspensions were atomized and sprayed into the drying chamber using a two-fluid nozzle. The product dried almost instantaneously, and the residence time was negligible. Three independent replicates were performed for each strain. Cell counts, before and after spray drying, were performed in MRS $\operatorname{agar}\left(72 \mathrm{~h}, 34^{\circ} \mathrm{C}\right.$, aerobiosis).

Cell suspensions (prepared as described above) were freezedried in a laboratory scale freeze dryer (Christ Alpha 1-4 LD Plus, Osterode am Harz, Germany). Freeze drying conditions were $0.002 \mathrm{mBar},-55^{\circ} \mathrm{C}, 20 \mathrm{~h}$. Three independent replicates were performed for each strain. Cell counts, before and after freeze drying, were performed in $\mathrm{MRS}$ agar $\left(72 \mathrm{~h}, 34^{\circ} \mathrm{C}\right.$, aerobiosis).

\section{Evaluation of the Selected Spray Dried Bacteria as Inoculants in Experimental Maize Silage}

Silage was made with fresh-cut maize using a small-scale system of silage fermentation (Cai et al., 1998; Johnson et al., 2005). Chopped maize was taken immediately to the lab for silage-making. Spray dried strains (L. plantarum Ls71, $P$. acidilactici Ls72, and L. buchneri Ls141) were prepared as described above. The silage treatments were designed as follows: (i) untreated control (UC) (sprayed with sterile water); (ii) substrate (S) (sprayed with a suspension of $20 \%(\mathrm{w} / \mathrm{v})$ maltodextrin-WPC); (iii) enzyme (E) (sprayed with $0.05 \%(\mathrm{w} / \mathrm{v})$ Acremonium fungal cellulase solution (Milar Enzimas S.R.L., Buenos Aires, Argentina); (iv) spray dried bacteria (SDB) [(SD culture resuspended in sterile water and sprayed on the forage to a final concentration (of each strain) of c.a. $5 \times 10^{6} \mathrm{CFU} / \mathrm{g}$ of cropped maize)], and (v) spray dried bacteria + enzyme (SDBE). All treatments were applied at a rate of $20 \mathrm{~mL} / \mathrm{kg}$ of the corresponding solution. Approximately $400 \mathrm{~g}$ portions of each treatment (in triplicate, for each sampling day) were vacuumpackaged (Turbovac, Bosch) in $200 \times 450 \mathrm{~mm}$, 58 microns, 
high barrier shrink bags (Cryovac: BC40LA) OTR (Oxygen Transmission Rate: $10-18\left[\left(\mathrm{~cm}^{3} / \mathrm{m}^{2}\right) \times 24 \mathrm{~h} \times\right.$ bar $\left.]\right)$. The microsilos were stored at room temperature $\left(25^{\circ} \mathrm{C}\right)$ for 60 days. $\mathrm{pH}$ was measured after $0,4,7,30$, and 60 days of fermentation. Ten grams of each sample were added with $90 \mathrm{~mL}$ of sterile distilled water and homogenized (stomacher, $120 \mathrm{~s}$, low power). Microbiological analyses and quantification of organic acids and carbohydrates by HPLC (Vénica et al., 2014) were carried out at the beginning and after 30 and 60 days of storage. Total LAB were enumerated in MRS agar $\left(34^{\circ} \mathrm{C}, 48 \mathrm{~h}\right.$, aerobiosis) and yeasts and filamentous fungi in chloramphenicol glucose agar (Biokar, Beauvais, France) $\left(25^{\circ} \mathrm{C}, 7 \mathrm{~d}\right.$, aerobiosis). Chemical analyses were performed after 30 [Dry Matter (g/kg DM; PROMEFA-v2 AOAC, $1990 \mathrm{~N}^{\circ} 130.15$ and $\mathrm{N}^{\circ}$ 167.03), pH, Ammonia Nitrogen/Total Nitrogen $\left(\mathrm{N}_{\mathrm{NH} 3} / \mathrm{N}_{\mathrm{T}}\right.$; Blain and Urtinett, 1954) and Crude Protein (g/kg CP; AOAC, $1998 \mathrm{~N}^{\circ}$ 976.05)] and 60 days of fermentation [DM, pH, $\mathrm{N}_{\mathrm{NH} 3} / \mathrm{N}_{\mathrm{T}}, \mathrm{CP}$, Ash $(\mathrm{g} / \mathrm{kg})$, Acid Detergent Insoluble Nitrogen/Total Nitrogen (NADIN/NT). Acid detergent fiber in feeds. Filter bag technique, Ankom200), Acid Detergent Fiber (g/kg ADF; ANKOM Method validated with ISO13906:2008), Neutral Detergent Fiber (g/kg NDF; ANKOM Method validated with ISO16472:2006), and Metabolisable Energy (ME; Mcal/kg DM)] (Laboratorio de Análisis de Forrajes, Concentrados e Insumos Agropecuarios de la Facultad de Ciencias Agrarias (FCA), UNL, Esperanza, Santa Fe, Argentina). Analyses were carried out in triplicate.

\section{Bucket Silos and Aerobic Stability Measurement}

Chopped maize was taken immediately to the lab for silagemaking. Spray dried strains (L. plantarum Ls71, P. acidilactici Ls72, and L. buchneri Ls141) were prepared as described in 2.7. For these assay two groups were used: UC and SDB-E. Both treatments were prepared as described above and bacteria were sprayed to a final concentration of $5 \times 10^{6} \mathrm{CFU} / \mathrm{g}$ of cropped maize. Twelve kilograms bucked silos were prepared (in triplicate), compacted, sealed and stored at room temperature $\left(25^{\circ} \mathrm{C}\right)$ during 50 days. At the end of the fermentation period, $\mathrm{pH}$ and cell counts of total LAB and yeast and filamentous fungi were determined.

Two kilograms of well-mixed silage from the medium portion of each bucket silo (free of visible spoilage) were placed back (without packing) into clean plastic bags (2 bags for each silo, placed inside an expanded polystyrene box covered with a cloth). A digital indoor-outdoor thermometer (Boeco, Hamburg, Germany) was inserted into the center of each silage mass and the temperature was recorded four times a day. The aerobic stability was defined as the time taken to increase the temperature of the feed by $2^{\circ} \mathrm{C}$ above the ambient temperature (Reich and Kung, 2010).

\section{Statistical Analysis}

Data were analyzed using the one-way ANOVA procedure of SPSS software (SPSS Inc., Chicago, IL, United States). The differences between means were detected by Tukey and Duncan's
Multiple Range test. Data were considered significantly different when $P<0.05$.

\section{RESULTS}

\section{Isolation and Identification of LAB}

Out of 22 isolates, 11 presumptive LAB were subjected to genetic identification by sequencing the $16 \mathrm{~S}$ region of the rDNA, resulting in Lactobacillus plantarum (Ls71 and Hv75); Lactobacillus amylovorus (Hv142, Hv212, and Hv214); Lactobacillus panis (Hv71, Hv73, and Hv77); Lactobacillus fermentum Hv76, Lactobacillus buchneri Ls141, and Pediococcus acidilactici Ls72. Lactobacillus strains were originally isolated from MRS agar and P. acidilactici Ls72 from M17 agar. Silage origin of the strains is shown in Table $\mathbf{1 .}$

\section{Growth Kinetics}

Cell growth parameters ( $\mu_{\max }$ and $\lambda$ ) at 30,34 , and $37^{\circ} \mathrm{C}$ are shown in Table 1 . Since only $P$. acidilactici Ls72 showed a fast growth kinetic at $43^{\circ} \mathrm{C}$, the data, at this temperature, were not modeled. For all the strains, except for L. panis Hv71, Hv73, and Hv77 since they presented poor growth capacity after several transfers in MRS broth, the most suitable growth temperatures were 34 and $37^{\circ} \mathrm{C}$ (Table 1). L. plantarum Ls71 and L. fermentum Hv76 showed the shortest lag phase both at $34^{\circ} \mathrm{C}$ and $37^{\circ} \mathrm{C}$ while L. buchneri Ls141 showed a long exponential phase until almost $13-14 \mathrm{~h}$ of culture. At $30^{\circ} \mathrm{C}$, almost all the strains had a longer $\lambda$. The cell growth $\left(\Delta \log _{10} \mathrm{CFU} / \mathrm{mL}\right)$ after $24 \mathrm{~h}$ at the different temperatures is shown in Figure 1. P. acidilactici Ls72 was the only strain able to grow at the four temperatures assessed. L. buchneri Ls 141 was not able to grow at 30 or $43^{\circ} \mathrm{C}$. The results indicate that most of the isolates are mesophilic LAB. For further studies, a growth temperature of $34^{\circ} \mathrm{C}$ was chosen.

\section{Growth Kinetics in Vegetable-Based Medium and Determination of Organic Acids and Carbohydrates by HPLC}

The capacity to grow in the VBM was strain-dependent (Figure 2). L. buchneri Ls141 showed the highest growth capacity ( $>2 \log _{10} \mathrm{CFU} / \mathrm{mL}$ after $24 \mathrm{~h}$ of incubation) while $P$. acidilactici Ls72 was able to grow only $0.3 \log _{10} \mathrm{CFU} / \mathrm{mL}$ (after $48 \mathrm{~h}$ ). Most of the strains grew between 0.6 and $1.1 \log _{10} \mathrm{CFU} / \mathrm{mL}$ after $24 \mathrm{~h}$ of incubation and then viability loss was observed, except for L. buchneri Ls141 that showed a maximum growth at $48 \mathrm{~h}$.

The determination of organic acids and carbohydrates was performed after $72 \mathrm{~h}$ of fermentation (Table 2). Two peaks with retention time similar to glucose and fructose were detected in the chromatograms with IR detector. It is important to highlight that sucrose is hydrolyzed during the analysis due to the chromatography conditions used (high temperature and low pH) (Vénica et al., 2014). So, the results of glucose and fructose are the sum of the basal level in the maize and that providing from sucrose hydrolysis, if it were present. Propionic acid was not detected in any of the samples. L. plantarum Ls71 and L. plantarum Hv75 produced the highest amounts of 
TABLE 1 | Identification, description of the kinetic growth parameters ( $\mu_{\max }$ and $\lambda$ ) and optimal growth temperatures of $L A B$ isolated from silages at different times of fermentation.

\begin{tabular}{|c|c|c|c|c|c|c|c|c|c|c|c|}
\hline \multirow[t]{2}{*}{ Isolate $\mathbf{N}^{\circ}$} & \multirow{2}{*}{$\begin{array}{l}\text { Silage } \\
\text { origin }\end{array}$} & \multirow{2}{*}{$\begin{array}{l}\text { Day of } \\
\text { isolation }\end{array}$} & \multirow[t]{2}{*}{ Identification } & \multirow{2}{*}{$\begin{array}{l}\text { Strain } \\
\text { name }\end{array}$} & \multicolumn{3}{|c|}{$\mu_{\max }$} & \multicolumn{3}{|c|}{$\lambda$} & \multirow{2}{*}{$\begin{array}{l}\text { Optimal growth } \\
\text { temperature }\left({ }^{\circ} \mathrm{C}\right)\end{array}$} \\
\hline & & & & & $30^{\circ} \mathrm{C}$ & $34^{\circ} \mathrm{C}$ & $37^{\circ} \mathrm{C}$ & $30^{\circ} \mathrm{C}$ & $34^{\circ} \mathrm{C}$ & $37^{\circ} \mathrm{C}$ & \\
\hline 1 & Recreo & 7 & L. plantarum & Ls71 & 0.31 & 0.27 & 0.27 & 3.25 & 2.83 & 2.68 & $34-37$ \\
\hline 2 & Recreo & 7 & P. acidilactici & Ls 72 & 0.22 & 0.13 & 0.17 & 3.38 & 3.08 & 2.54 & $34-37$ \\
\hline 3 & Recreo & 14 & L. buchneri & Ls141 & 0.10 & 0.08 & 0.06 & 15.50 & 13.00 & 14.10 & $34-37$ \\
\hline 4 & Esperanza & 7 & L. plantarum & $\mathrm{H} v 75$ & 0.31 & 0.35 & 0.33 & 3.12 & 4.47 & 2.98 & $34-37$ \\
\hline 5 & Esperanza & 7 & L. fermentum & Hv76 & 0.13 & 0.19 & 0.17 & 2.74 & 2.08 & 1.37 & $34-37$ \\
\hline 6 & Esperanza & 21 & L. amylovorus & Hv214 & 0.07 & 0.15 & 0.23 & 12.7 & 6.09 & 5.48 & 37 \\
\hline 7 & Esperanza & 21 & L. amylovorus & Hv212 & 0.11 & 0.15 & 0.19 & 7.52 & 4.91 & 5.34 & $34-37$ \\
\hline 8 & Esperanza & 14 & L. amylovorus & Hv142 & 0.15 & 0.16 & 0.21 & 5.96 & 3.25 & 2.32 & 37 \\
\hline 9 & Esperanza & 7 & L. panis & $\mathrm{H} v 73$ & nd & nd & nd & nd & nd & nd & nd \\
\hline 10 & Esperanza & 7 & L. panis & Hv71 & nd & nd & nd & nd & nd & nd & nd \\
\hline 11 & Esperanza & 7 & L. panis & $\mathrm{Hv} 77$ & nd & nd & nd & nd & nd & nd & nd \\
\hline
\end{tabular}

$\mu_{\max }$, the maximum specific growth rate as variation of $0 . D_{560 \mathrm{~nm} / \mathrm{h} . ;} \lambda$, lag time in hours. Nd, not detected.

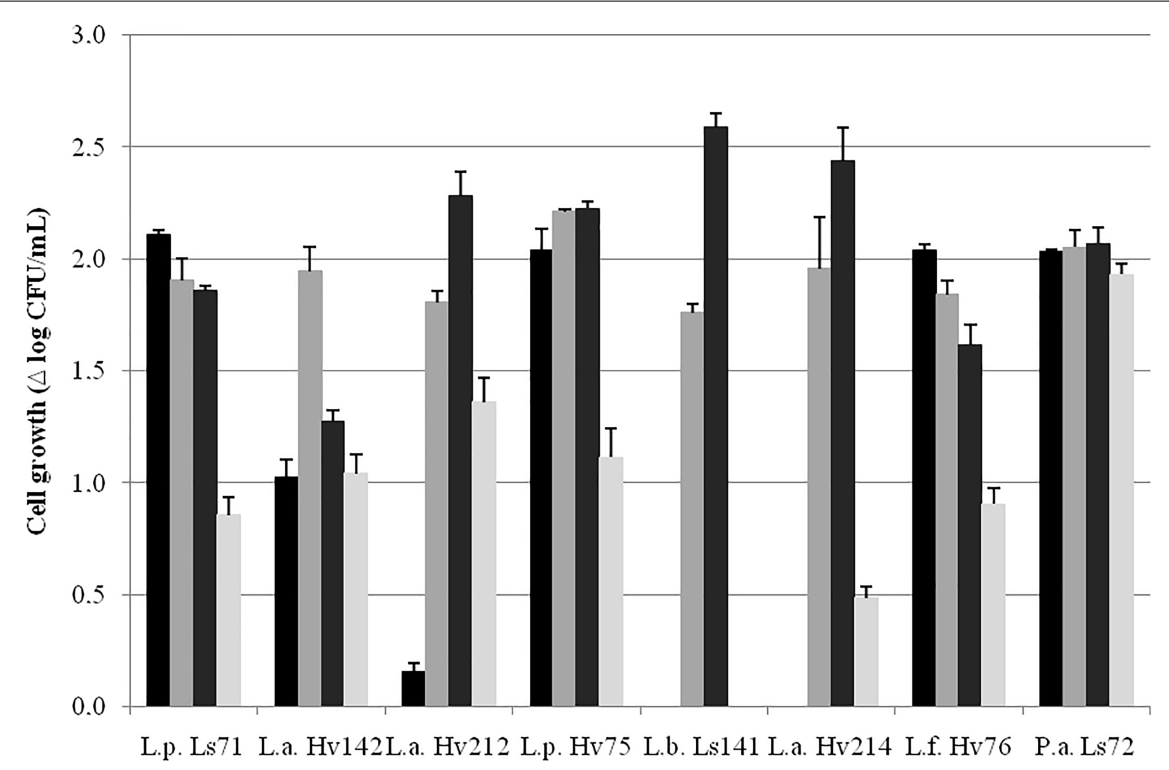

FIGURE 1 | Cell growth in MRS broth ( $\Delta \log _{10} \mathrm{CFU} / \mathrm{mL} \pm \mathrm{SEM}$ ) at $30(\mathbf{\square}), 34(\mathbf{\square}), 37(\mathbf{\square})$, and $43(\mathbf{\square}){ }^{\circ} \mathrm{C}$ after $24 \mathrm{~h}$, aerobiosis.

lactic acid which correlated with the lowest $\mathrm{pH}$ values and an increased consumption of carbohydrates (concentration below the detection limit). L. buchneri Ls141 and L. fermentum Hv76 produced the highest amounts of acetic acid and the lowest concentrations of lactic acid. $\mathrm{pH}$ values were above 4 and there was less consumption of carbohydrates. L. amylovorus Hv212, Hv214, and Hv142 acidified the VBM ( $\mathrm{pH} \approx 3.8$ ), no acetic acid was detected, and the concentration of lactic acid was between 1.1 and $1.5 \mathrm{mg} / \mathrm{mL}$.

\section{Tolerance to Heat Stress}

Heat-resistance results (cell death after 5 and $15 \mathrm{~min}$ at $55^{\circ} \mathrm{C}$ ) are shown in Figure 3. Heat tolerance was strain dependent. $P$. acidilactici Ls72 was the most resistant strain, with a reduction in cell viability of $0.2 \log _{10} \mathrm{CFU} / \mathrm{mL}$ both after 5 and $15 \mathrm{~min}$. After
5 min there was a cell death between 0.2 and $3.8 \log _{10} \mathrm{CFU} / \mathrm{mL}$ for all the strains. It was expected that strains with higher thermal resistance will better resist dehydration by spray drying.

\section{Microbial Growth as Single or Co-culture in MRS and VBM}

For both MRS and VBM the initial inoculum of all the strains was about $2 \times 10^{6} \mathrm{CFU} / \mathrm{mL}$. Results are shown in Table 3. As pure culture, all the strains were able to grow more than $3 \log _{10}$ $\mathrm{CFU} / \mathrm{mL}$ in MRS broth. When the strains were co-cultured a cell growth of more than $2.1 \log _{10} \mathrm{CFU} / \mathrm{mL}$ was observed for all of them. When VBM was used, a cell growth between 1.16 and $1.89 \log _{10} \mathrm{CFU} / \mathrm{mL}$ was observed. The combination L. plantarum Ls71/P. acidilactici Ls72 and L. plantarum Ls71/L. buchneri Ls141 showed a cell growth of about $1 \log _{10} \mathrm{CFU} / \mathrm{mL}$ but when 


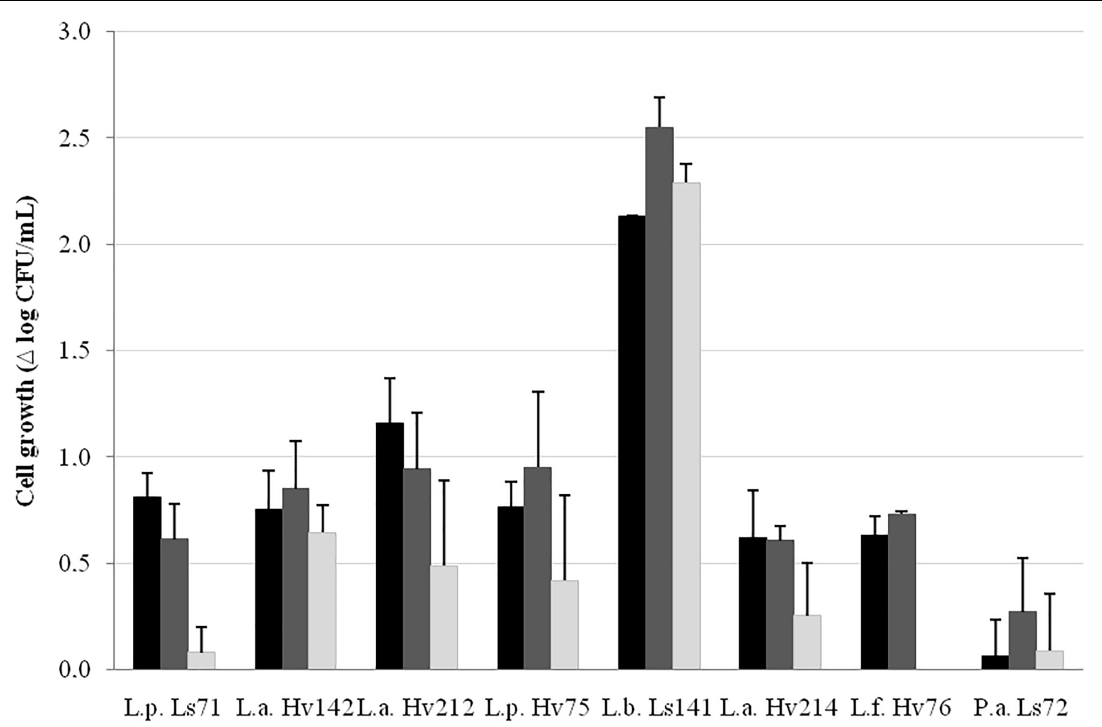

FIGURE 2 | Cell growth ( $\left.\Delta \log _{10} \mathrm{CFU} / \mathrm{mL} \pm \mathrm{SEM}\right)$ in VBM after $24(\boldsymbol{\square}), 48(\boldsymbol{\square})$, and $72 \mathrm{~h}(\boldsymbol{\square})$ at $34^{\circ} \mathrm{C}$, aerobiosis.

TABLE 2 | pH values and concentration of organic acids, glucose and fructose $(\mathrm{mg} / \mathrm{mL} \pm \mathrm{SD})$ in vegetable-based medium (VBM) after $72 \mathrm{~h}$ at $34^{\circ} \mathrm{C}$, anaerobiosis.

\begin{tabular}{|c|c|c|c|c|c|}
\hline \multirow[t]{2}{*}{ Strains } & \multirow[t]{2}{*}{$\mathrm{pH}$} & \multicolumn{4}{|c|}{ Concentration (mg/mL) } \\
\hline & & Lactic acid & Acetic acid* & Glucose $^{\#}$ & Fructose $\#$ \\
\hline L.b. Ls141 & $4.33 \pm 0.04$ & $0.82 \pm 0.01$ & $0.16 \pm 0.05$ & $0.20 \pm 0.03$ & $0.53 \pm 0.04$ \\
\hline L.p. Hv75 & $3.66 \pm 0.04$ & $2.41 \pm 0.15$ & $0.15 \pm 0.04$ & nd & nd \\
\hline L.p. Ls71 & $3.65 \pm 0.06$ & $2.35 \pm 0.05$ & $0.09 \pm 0.04$ & nd & nd \\
\hline L.a. Hv142 & $3.76 \pm 0.06$ & $1.51 \pm 0.07$ & nd & $0.27 \pm 0.04$ & $0.51 \pm 0.02$ \\
\hline L.f. Hv76 & $4.77 \pm 0.11$ & $0.59 \pm 0.08$ & $0.18 \pm 0.01$ & $0.42 \pm 0.08$ & $0.48 \pm 0.02$ \\
\hline L.a. Hv214 & $3.88 \pm 0.01$ & $1.21 \pm 0.01$ & nd & $0.36 \pm 0.07$ & $0.60 \pm 0.08$ \\
\hline L.a. Hv212 & $3.88 \pm 0.10$ & $1.14 \pm 0.15$ & nd & $0.31 \pm 0.02$ & $0.65 \pm 0.08$ \\
\hline P.a. Ls72 & $4.23 \pm 0.10$ & $1.01 \pm 0.09$ & nd & $0.41 \pm 0.09$ & $0.93 \pm 0.01$ \\
\hline VBM medium & 6.5 & nd & nd & 1.00 & 1.18 \\
\hline
\end{tabular}

nd, not detected. *Detection limit: $0.05 \mathrm{mg} / \mathrm{mL}$; " detection limit: $0.10 \mathrm{mg} / \mathrm{mL}$.

P. acidilactici Ls72 was cultured with L. buchneri Ls141 (or the 3 strains together) it was not able to grow.

\section{Resistance to Spray and Freeze-Drying}

All the strains exhibited satisfactory resistance to both dehydration processes. After freeze-drying, a cell death of $0.56 \pm 0.37,0.46 \pm 0.24$, and $0.33 \pm 0.38 \log _{10} \mathrm{CFU} / \mathrm{mL}$ was observed for L. buchneri Ls14, L. plantarum Ls71, and $P$. acidilactici Ls72, respectively. L. plantarum Ls71 was the most sensitive strain to spray dried with a loss of viability of $0.92 \pm 0.37 \log _{10} \mathrm{CFU} / \mathrm{mL}$. On the contrary, P. acidilactici Ls72 was the most resistant strain with a cell death of $0.02 \pm 0.19 \log _{10}$ $\mathrm{CFU} / \mathrm{mL}$ (viability rate $95 \pm 9 \%$ ).

\section{Evaluation of Selected Spray Dried Cultures as Inoculants in Experimental Maize Silage}

$\mathrm{pH}$ values of micro-silos after $0,4,7,30$, and 60 days of fermentation at $25^{\circ} \mathrm{C}$ are shown in Table 4. After 4 days of fermentation, all the samples reached a pH between 3.73 and 3.86 and these values remained stable until the end of the fermentation period.

Microbiological analyses are shown in Table 5. After 30 days of fermentation there was a significantly lower $(p<0.05)$ cell load of filamentous fungi and yeasts $\left(<3 \log _{10} \mathrm{CFU} / \mathrm{g}\right.$ ) for both inoculated micro-silos (SDB and SDB-E), compared to UC, S, and $\mathrm{E}$ samples. Likewise, the number of LAB was significantly higher for inoculated samples (more than $8.7 \log _{10} \mathrm{CFU} / \mathrm{g}$ ) and about $6 \log _{10} \mathrm{CFU} / \mathrm{g}$ for non-inoculated ones. After 60 days of fermentation neither filamentous fungi nor yeasts were detected in SDB and SDB-E $\left(<1 \log _{10} \mathrm{CFU} / \mathrm{g}\right)$ micro-silos, whereas counts higher than $5.3 \log _{10} \mathrm{CFU} / \mathrm{g}$ were found for UC, S, and E micro-silos.

The content of glucose (time $=0$ ) was significantly higher $(p<0.05)$ in samples where the enzyme was added $(1.50 \pm 0.04$, $1.30 \pm 0.04 ; 0.48 \pm 0.09 ; 0.38 \pm 0.08$, and $0.47 \pm 0.06 \mathrm{mg} / \mathrm{mL}$ for $\mathrm{E}, \mathrm{SDB}-\mathrm{E}, \mathrm{UC}, \mathrm{S}$, and SDB, respectively) indicating a possible fast action of the enzyme liberating simple sugars for the fermentation. 


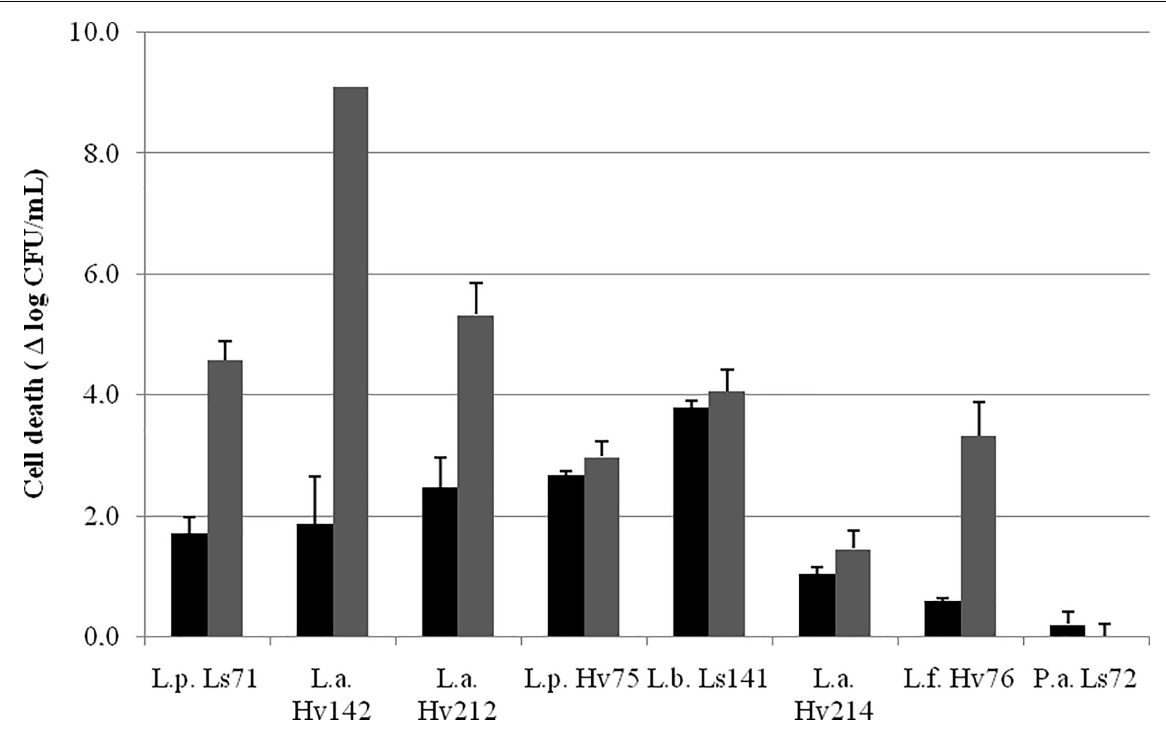

FIGURE 3 | Cell death $\left(\Delta \log _{10} \mathrm{CFU} / \mathrm{mL} \pm\right.$ SEM) after 5

and 15

$\min$ at $55^{\circ} \mathrm{C}$

TABLE 3 | Cell growth of strains ( $\Delta \log _{10} \mathrm{CFU} / \mathrm{mL} \pm \mathrm{SD}$ ) as single or co-cultured in MRS and VBM after $24 \mathrm{~h}$ at $34^{\circ} \mathrm{C}$, aerobiosis.

Strain/ combination

Cell growth ( $\left.\Delta \log _{10} \mathrm{CFU} / \mathrm{mL}\right)$

\begin{tabular}{|c|c|c|c|c|c|c|}
\hline & \multicolumn{3}{|c|}{ MRS } & \multicolumn{3}{|c|}{ VBM } \\
\hline L.p. Ls71 & \multicolumn{3}{|c|}{$3.14 \pm 0.30^{*}$} & \multicolumn{3}{|c|}{$1.89 \pm 0.33$} \\
\hline P.a. Ls72 & \multicolumn{3}{|c|}{$3.11 \pm 0.16^{*}$} & \multicolumn{3}{|c|}{$1.16 \pm 0.35$} \\
\hline \multirow[t]{2}{*}{ L.b. Ls141 } & & $3.04 \pm 0.02^{*}$ & & & $1.62 \pm 0.77$ & \\
\hline & Ls71 & Ls72 & Ls141 & Ls71 & Ls72 & Ls141 \\
\hline Ls71 Ls72 & $2.95 \pm 0.07$ & $2.78 \pm 0.21$ & - & $1.26 \pm 0.07$ & $1.26 \pm 0.20$ & - \\
\hline Ls71/Ls141 & $3.28 \pm 0.20$ & - & $2.35 \pm 0.03$ & $1.24 \pm 0.29$ & - & $0.93 \pm 0.04$ \\
\hline Ls141/Ls72 & - & $3.03 \pm 0.42$ & $2.15 \pm 0.83$ & - & $0.19 \pm 0.27$ & $1.12 \pm 0.37$ \\
\hline Ls71/Ls72/Ls141 & $2.82 \pm 0.25$ & $2.80 \pm 0.13$ & $2.47 \pm 0.46$ & $1.09 \pm 0.20$ & $0.52 \pm 0.01$ & $1.31 \pm 0.35$ \\
\hline
\end{tabular}

*The cell growth of each stain cultured in MRS differs significantly with respect to VBM $(p<0.05)$.

TABLE 4 | pH values of micro-silos (mean \pm SD) after 0, 4, 7, 30, and 60 days of fermentation at $25^{\circ} \mathrm{C}$.

\begin{tabular}{lccccc}
\hline Sample & \multicolumn{5}{c}{ Days of ensiling } \\
\cline { 2 - 6 } & $\mathbf{0}$ & $\mathbf{4}$ & $\mathbf{7}$ & $\mathbf{3 0}$ & $\mathbf{6 0}$ \\
\hline UC & $5.90 \pm 0.09$ & $3.84 \pm 0.01$ & $3.81 \pm 0.01$ & $3.78 \pm 0.00$ & $3.75 \pm 0.01$ \\
S & $5.90 \pm 0.09$ & $3.86 \pm 0.06$ & $3.84 \pm 0.01$ & $3.79 \pm 001$ & $3.80 \pm 0.02$ \\
E & $5.90 \pm 0.09$ & $3.84 \pm 0.03$ & $3.75 \pm 0.01$ & $3.73 \pm 0.02$ & $3.78 \pm 0.07$ \\
SDB & $5.90 \pm 0.09$ & $3.74 \pm 0.00 *$ & $3.72 \pm 0.02$ & $3.80 \pm 0.03$ & $3.90 \pm 0.08$ \\
SDB+E & $5.90 \pm 0.09$ & $3.73 \pm 0.02 *$ & $3.71 \pm 0.03$ & $3.73 \pm 0.02$ & $3.73 \pm 0.03$ \\
\hline
\end{tabular}

*Values within the same time differ significantly with respect to UC group $(p<0.05)$. UC, untreated control; $S$, substrate; $E$, enzyme; $S D B$, spray dried bacteria; $S D B-E$, spray dried bacteria + enzyme.

The content of acetic acid was significantly higher $(p<0.05)$ in SDB and SDB-E samples after 30 (data not shown) and 60 days of fermentation compared to UC (Table 6), indicating the production of this acid by the added heterofermentative bacteria.
After 30 days of fermentation, no differences in DM content ( $\mathrm{g} / 100 \mathrm{~g}$ forage) and $\mathrm{pH}$ values were observed. However, the content of $\mathrm{N}_{\mathrm{NH} 3} / \mathrm{N}_{\mathrm{T}}$ and CP was significantly higher $(p<0.05)$ in SDB-E micro-silos compared to UC (data not shown).

Chemical analyses after $60 \mathrm{~d}$ of fermentation are shown in Table 6. No differences were found for DM content among samples (data not shown). In SDB-E micro-silos the content of $\mathrm{N}_{\mathrm{NH} 3} / \mathrm{N}_{\mathrm{T}}$ and CP was significantly higher $(p<0.05)$, whereas that of $\mathrm{N}_{\mathrm{ADIN}} / \mathrm{N}_{\mathrm{T}}$ was significantly lower $(p<0.05)$ compared to the other groups. No differences were observed for NDF, ADF, and ME concentrations between samples, except for E microsilos. Ash content was significantly higher $(p<0.05)$ in S, SDB, and SDB-E micro-silos compared to UC.

\section{Bucket Silos and Aerobic Stability Measurement}

After 50 days of fermentation, the $\mathrm{pH}$ values were $3.66 \pm 0.02$ and $3.73 \pm 0.02$ for UC and SDB-E bucket silos, respectively. 
TABLE 5 | Microbiological analyses ( $\log _{10} \mathrm{CFU} / \mathrm{g} \pm \mathrm{SD}$ ) of micro-silos during storage at $25^{\circ} \mathrm{C}$.

\begin{tabular}{|c|c|c|c|c|c|c|}
\hline Sample & \multicolumn{6}{|c|}{ Cell count $\left(\log _{10} \mathrm{CFU} / \mathrm{g} \pm \mathrm{SD}\right)$} \\
\hline UC & $5.63 \pm 0.21$ & $7.09 \pm 0.09$ & $4.14 \pm 0.81$ & $6.00 \pm 0.01$ & $5.59 \pm 0.16$ & $6.91 \pm 1.13$ \\
\hline S & $5.63 \pm 0.21$ & $7.09 \pm 0.09$ & $3.30 \pm 0.43$ & $6.15 \pm 0.21$ & $5.37 \pm 0.58$ & $7.32 \pm 0.58$ \\
\hline SDB-E & $5.63 \pm 0.21$ & $7.09 \pm 0.09$ & $<3^{*}$ & $8.77 \pm 0.01^{*}$ & $<1^{*}$ & $7.76 \pm 0.04$ \\
\hline
\end{tabular}

*Values within the same time differ significantly with respect to UC group $(p<0.05)$. UC, untreated control; S, substrate; E, enzyme; SDB, spray dried bacteria; SDB-E, spray dried bacteria + enzyme.

TABLE 6 | Chemical analyses of micro-silos (mean \pm SD) after 60 days of storage at $25^{\circ} \mathrm{C}$.

\begin{tabular}{|c|c|c|c|c|c|c|c|c|}
\hline Sample & Acetic acid $(\mathrm{mg} / \mathrm{mL})$ & $\mathrm{N}_{\mathrm{NH} 3} / \mathrm{N}_{\mathrm{T}}(\%)$ & Ash (\%) & CP (\%) & NDF (\%) & ADF (\%) & $\mathbf{N}_{\text {ADIN }} / \mathbf{N}_{\mathrm{T}}(\%)$ & ME (Mcal/kg DM) \\
\hline UC & $0.64 \pm 0.01^{\mathrm{a}}$ & $6.13 \pm 0.32^{\mathrm{a}}$ & $4.10 \pm 0.50^{\mathrm{a}}$ & $8.03 \pm 0.31^{a}$ & $24.17 \pm 5.15^{a}$ & $13.67 \pm 2.15^{a}$ & $3.67 \pm 1.04^{a}$ & $2.82 \pm 0.05^{a}$ \\
\hline S & $0.78 \pm 0.02^{\mathrm{a}}$ & $6.70 \pm 0.62^{\mathrm{a}}$ & $4.90 \pm 0.36^{b}$ & $8.13 \pm 0.45^{a}$ & $27.17 \pm 1.81^{a}$ & $15.80 \pm 1.28^{\mathrm{a}}$ & $3.30 \pm 0.62^{\mathrm{a}}$ & $2.77 \pm 0.03^{a}$ \\
\hline SDB & $1.29 \pm 0.19^{b}$ & $7.20 \pm 0.95^{a}$ & $5.00 \pm 0.44^{b}$ & $8.50 \pm 0.35^{a}$ & $23.50 \pm 2.92^{\mathrm{a}}$ & $12.90 \pm 1.31^{a}$ & $2.87 \pm 0.67^{a}$ & $2.84 \pm 0.04^{a}$ \\
\hline SDB-E & $1.92 \pm 0.22^{C}$ & $8.90 \pm 0.17^{b}$ & $5.53 \pm 0.15^{b}$ & $8.83 \pm 0.38^{b}$ & $18.63 \pm 1.21^{a}$ & $10.57 \pm 1.44^{\mathrm{a}}$ & $1.47 \pm 0.55^{\mathrm{b}}$ & $2.90 \pm 0.03^{a}$ \\
\hline
\end{tabular}

a,bValues with different superscripts differ significantly $(p<0.05)$. UC, untreated control; S, substrate; E, enzyme; SDB, spray dried bacteria; SDB-E, spray dried bacteria + enzyme. Values referred to dry basis.

Total number of viable LAB was significantly higher $(p<0.05)$ in SDB-E than in UC samples $\left(8.49 \pm 0.22\right.$ and $7.11 \pm 0.62 \log _{10}$ $\mathrm{CFU} / \mathrm{g}$, respectively) and a significantly lower cell load of yeast and filamentous fungi was found in inoculated silos compared with controls ( $2.36 \pm 1.92$ and $6.51 \pm 0.12$, respectively). This phenomenon was also checked visually when the bucket silos were opened.
Figure 4 shows the temperature $\left(\mathrm{T}_{\text {silo }}-\mathrm{T}_{\text {ambient }}\right)$ of the silos during 17.5 days $(420 \mathrm{~h})$. The aerobic stability was significantly improved $(p<0.05)$ in SDB-E silos compared with controls since an increase of about $5^{\circ} \mathrm{C}$ was observed in UC samples after $24 \mathrm{~h}$. On the contrary, the temperature of SDB-E silos remained stable for more than 15 days $(360 \mathrm{~h})$. Moreover, two maximum temperature picks were

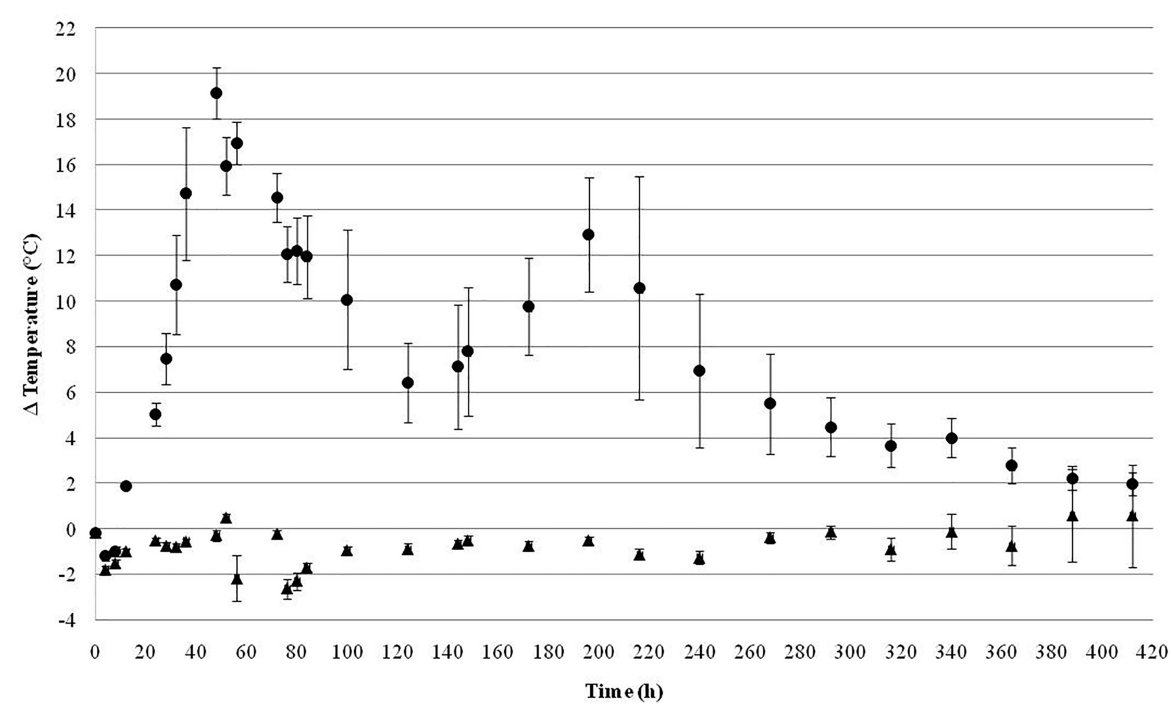

FIGURE 4 | Aerobic stability of silages during time expressed as $\Delta$ temperatures $\left({ }^{\circ} \mathrm{C}\right)$ : the ambient temperature was subtracted from the temperature measured

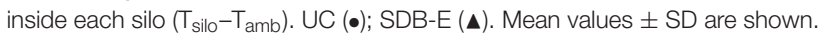


detected after $2(48 \mathrm{~h})$ and 8.16 days $(196 \mathrm{~h})$ in UC silos.

\section{DISCUSSION}

Plants are a natural habitat for certain species of LAB since these bacteria can be found on their surfaces. Even though the role of LAB on plants is not known, it is believed that they have a protective effect against pathogenic microorganisms by producing antagonistic compounds. After harvesting and compressing the plant material, Enterococcus faecalis and Leuconostoc mesenteroides usually initiate the fermentation. These are, in turn, replaced by more acid-tolerant species such as L. brevis, L. plantarum, and L. buchneri (Holzer et al., 2003). LAB species identified in our work correspond to those commonly found in silages (Dunière et al., 2013; Muck, 2013; Santos et al., 2013). Out of 22 isolates, 5 were obtained from silages harvested in Esperanza (from which 3 were selected for further studies), and 17 were obtained from silages harvested in Recreo (from which 8 were selected for further characterization). The criteria that were taken into account to select preliminary different isolates were: silage origin, macroscopic characteristics of the colonies grown in different media, gas production and cellular morphology (examined by phase-contrast microscopy, 1000x). Most of the strains were isolated after 7 days of natural fermentation of maize; L. buchneri Ls141 was isolated after 14 days and L. amylovorus strains were isolated after 14 or 21 days of fermentation (Table 1).

Some published data suggest that Pediococcus species would be responsible for starting the acidification process in silage when the growth of Lactobacillus strains is not favored because of the high $\mathrm{pH}$ value of the forage (Muck, 2013).

A successful application of inoculants in silage is based on the compatibility between the plant and the microorganisms used. This compatibility can be assessed by the ability of the microorganisms to use carbohydrates present in the forage and to produce metabolites of interest, primarily in the preservation of silage (e.g., acetic and lactic acids) (Ávila et al., 2014). In our study, L. buchneri Ls141 showed the highest growth ability in VBM after 24 and $48 \mathrm{~h}$ of incubation at $34^{\circ} \mathrm{C}$ and both $L$. plantarum strains (Ls71 and Hv75) produced the largest amounts of lactic acid. L. plantarum is a homofermentative LAB when glucose is not a limiting factor, otherwise, it is a facultatively heterofermentative strain. This fact could explain the production of acetic acid by these strains.

Three strains were selected for further characterization and to study their performance as a spray dried culture in maize micro and bucket silos. Selected strains were L. plantarum Ls71 since it showed a high growth rate in MRS broth at $34^{\circ} \mathrm{C}$ and a high capability to produce lactic acid in VBM; $P$. acidilactici Ls72 because it was the most heat-resistant strain and L. buchneri Ls141 which showed good growth ability in VBM and it is a heterofermentative LAB that produces acetic acid. Moreover, these LAB species are normally found in commercial inoculants.

Regarding the capacity of the selected strains able to grow in co-culture in MRS broth and VBM, satisfactory results were obtained in MRS; nevertheless, inhibition was detected for
P. acidilactici Ls72 when cultured together with L. buchneri Ls141 in VBM. Although it would appear that L. buchneri Ls141 inhibits, in vitro, the growth of $P$. acidilactici Ls72, this does not imply that the same fact would happen in silage, which is a more complex environment.

Important challenges to overcome by a strain for its industrial use are the stressors found during manufacture and storage. The three selected strains tolerated satisfactorily both spray and freeze-drying. $P$. acidilactici Ls72 was the most heat resistant strain and showed the highest resistance to spray and freezedrying. While freeze-drying is most commonly used, other drying processes for microorganism preservation have been tested. Spray drying is a low-cost alternative to freeze-drying (only $12-20 \%$ of the cost of freeze-drying) and allows the production of large amounts of dried cells in a continuous process. The feasibility to apply spray-drying to LAB will depend on the technological conditions applied (Peralta et al., 2017; Uang et al., 2017; Reale et al., 2019). To the best of our knowledge, there are no spray dried silage inoculants in the market so far. Most of them are commercialized as freeze-dried powders or as water-soluble concentrates for which a strict cold chain is needed to warrant high cell viability.

In this study, the performance of three selected SD LAB was evaluated in maize micro and bucket-silos. Moreover, it was checked that the matrix used to spray dry the cells had no influence on the fermentation process. The most common measurements used for evaluating silage fermentation are $\mathrm{pH}$, the concentration of organic acids, alcohols, $\mathrm{NH}_{3} / \mathrm{N}$ and microbial populations (Kung et al., 2018). Even though after 4 days of fermentation at $25^{\circ} \mathrm{C}$ the $\mathrm{pH}$ values of all samples were lower than 3.9, indicating that natural fermentation had occurred, a faster decrease was observed in both inoculated micro-silos (SDB and SDB-E). Maize silages normally have a final $\mathrm{pH}$ of 3.7-4.0 because it is a crop that has a low buffering capacity. The low $\mathrm{pH}$ from lactic acid stabilizes silage fermentation by inhibiting the growth of or killing acid-intolerant microorganisms (Kung et al., 2018). Furthermore, a significantly lower cell load of yeasts and filamentous fungi was found in inoculated micro-silos after 30 days and levels lower than $1 \log _{10} \mathrm{CFU} / \mathrm{g}$ were found at the end of the fermentation period (60 days). Similar results were found in bucket silos after 50 days of fermentation.

The use of $\mathrm{LAB}$ as bio-preservative agents in food due to their antimicrobial activity is well documented. Among LAB, several strains of L. plantarum are known for their ability to produce antifungal substances (Laitila et al., 2002; Sorrentino et al., 2013). Russo et al. (2017) reported that phenyllactic acid production by $L$. plantarum has been associated with the antifungal activity against strains belonging to species of Aspergillus, Penicillium, and Fusarium. Therefore, the use of L. plantarum Ls71 in inoculated silages could have contributed to the control of filamentous fungi. On the other hand, the reduction in the number of undesirable microorganisms could also be attributed to the production of acetic acid by L. buchneri Ls141 which correlated with the highest concentration of acetic acid in SDB $(0.90 \pm 0.03$ and $1.29 \pm 0.19 \mathrm{mg} / \mathrm{mL})$ and SDB-E $(1.40 \pm 0.33$ and $1.92 \pm 0.22 \mathrm{mg} / \mathrm{mL}$ ) micro-silos after 30 and 60 days of fermentation, respectively. Reich and Kung (2010) reported that 
the cell load of yeasts was extremely low or no detectable in silages treated with the strain L. buchneri 40788 and higher than $4 \log _{10}$ $\mathrm{CFU} / \mathrm{g}$ in control samples. Additionally, the number of total LAB was higher in inoculated than in control silos. In a meta-analysis of the effects of Lactobacillus buchneri on the fermentation and aerobic stability of maize and grass and small-grain silages, Kleinschmit and Kung (2006) suggested that treatment of maize silage with the lower application rates of L. buchneri $\left(<10^{5} \mathrm{CFU} / \mathrm{g}\right.$ of fresh forage) resulted in a 10 -fold decrease in numbers of yeasts compared with the untreated silage and, the treatment with LB2 ( $>10^{5} \mathrm{CFU} / \mathrm{g}$ of fresh forage) decreased the numbers of yeasts more than 100-fold.

After 30 days of fermentation chemical analyses in micro-silos showed that there was no amino acid degradation, deamination or excessive degradation of proteins. Plant and microbial proteolytic activity lead to changes in nitrogenous compounds in silages. Both E and SDB-E micro-silos showed the highest values of $\mathrm{N}_{\mathrm{NH} 3} / \mathrm{N}_{\mathrm{T}}(6.63 \pm 0.67$ and $6.07 \pm 0.61 \%$, respectively), which could be due to the addition of cellulase.

After 60 days of fermentation, the $\mathrm{pH}$ remained below 3.90 for all samples. Values of NDF and ADF were significantly lower in $\mathrm{E}$ and SDB-E micro-silos compared to UC. Values of $\mathrm{N}_{\mathrm{ADIN}} / \mathrm{N}_{\mathrm{T}}$ remained below 15\%, indicating that there was no production of indigestible compounds, with a significant reduction observed in SDB-E samples.

The continuous infiltration of air during the storage period of the forage in the silo facilitates the growth of aerobic microorganisms that metabolize organic matter to generate a disposable rotten material for use in animal feed. In general, acid-tolerant and lactate-assimilating yeasts initiate this process of deterioration by consuming carbohydrates and acids produced during fermentation, which generates an increase in the temperature and $\mathrm{pH}$ of the ensiled material (Borreani et al., 2018; Kung et al., 2018). In our work, no significantly heating

\section{REFERENCES}

Ávila, C. L. S., Carvalho, B. F., Pinto, J. C., Duarte, W. F., and Schwan, R. F. (2014). The use of Lactobacillus species as starter cultures for enhancing the quality of sugar cane silage. J. Dairy Sci. 97, 940-951. doi: 10.3168/jds.2013-6987

Blain, J. M., and Urtinett, M. A. (1954). Détermination de l'ammoniac dans les ensilages in Conférence Européene des Herbasges. Paris 21-24, 304-314.

Borreani, G., Tabacco, E., Schmidt, R. J., Holmes, B. J., and Muck, R. E. (2018). Silage review: factors affecting dry matter and quality losses in silages. J. Dairy Sci. 101, 3952-3979. doi: 10.3168/jds.2017-13837

Cai, Y., Benno, Y., Ogawa, M., Ohmomo, S., Kumai, S., and Nakase, T. (1998). Influence of Lactobacillus spp. from an inoculant and of Weissella and Leuconostoc spp. from forage crops on silage fermentation. Appl. Environ. Microbiol. 64, 2982-2987.

Dunière, L., Sindou, J., Chaucheyras-Durand, F., Chevallier, I., and ThévenotSergentet, D. (2013). Silage processing and strategies to prevent persistence of undesirable microorganisms. Anim. Feed Sci. Technol. 182, 1-15. doi: 10.1016/ j.anifeedsci.2013.04.006

Edwards, U., Rogall, T., Blöcker, H., Emde, M., and Böttger, E. C. (1989). Isolation and direct complete nucleotide determination of entire genes. Characterization of a gene coding for 16S ribosomal RNA. Nucleic Acids Res. 17, 7843-7853. doi: 10.1093/nar/17.19.7843

Holzer, M., Mayrhuber, E., Danner, H., and Braun, R. (2003). The role of Lactobacillus buchneri in forage preservation. Trends Biotechnol. 21, 282-287. doi: 10.1016/S0167-7799(03)00106-9 was observed in SDB-E silos after 15 days (360 h), indicating a high aerobic stability. These results correlated with the lower number of yeast and filamentous fungi found in inoculated silages compared to controls.

Literature data suggest that L. buchneri successfully improves the aerobic stability of a variety of silages; however, the effects are strain-specific and dose-dependent (Muck et al., 2018).

\section{CONCLUSION}

In this work, eleven strains belonging to six species of LAB were isolated from naturally fermented maize silage. After characterization, L. plantarum Ls71, P. acidilactici Ls72, and L. buchneri Ls 141 were selected to be dehydrated by spray-drying and to evaluate their performances in micro and bucket-silos. Results indicate that the selected strains have the potential to be produced as a SD silage inoculant for maize ensiling since they accelerated the fermentation process, controlled the development of filamentous fungi and yeasts, improved some nutritional and chemical relevant silage quality variables and significantly enhanced aerobic stability.

\section{AUTHOR CONTRIBUTIONS}

$\mathrm{PB}$ and $\mathrm{MB}$ designed the study, analyzed data, and contributed to the writing of the manuscript. RP was responsible for the spray drying treatments and for the optimization of the drying process. AB performed the molecular identification of the strains. MP contributed to the experimental design of the work and to the writing of the manuscript. CB performed the HPLC analysis. $\mathrm{JR}, \mathrm{GV}$, and RM participated in the writing and revision of the manuscript and scientific discussions.

Johnson, H. E., Merry, R. J., Davies, D. R., Kell, D. B., Theodorou, M. K., and Griffith, G. W. (2005). Vacuum packing: a model system for laboratoryscale silage fermentations. J. Appl. Microbiol. 98, 106-113. doi: 10.1016/S01677799(03)00106-9

Kleinschmit, D. H., and Kung, L. (2006). A Meta-analysis of the effects of Lactobacillus buchneri on the fermentation and aerobic stability of corn and grass and small-grain silages. J. Dairy Sci. 89, 4005-4013. doi: 10.3168/jds. S0022-0302(06)72444-4

Kung, L. Jr., Shaver, R. D., Grant, R. J., and Schmidt, R. J. (2018). Silage review: interpretation of chemical, microbial, and organoleptic components of silages. J. Dairy Sci. 101, 4020-4033. doi: 10.3168/jds.201713909

Laitila, A., Alakomi, H. L., Raaska, L., Mattila-Sandholm, T., and Haikara, A. (2002). Antifungal activities of two Lactobacillus plantarum strains against Fusarium moulds in vitro and in malting of barley. J. Appl. Microbiol. 93, 566-576. doi: 10.1046/j.1365-2672.2002.01731.x

Lin, C., Bolsen, K. K., Brent, B. E., and Fung, D. Y. C. (1992). Epiphytic lactic acid bacteria succession during the pre-ensiling and ensiling periods of alfalfa and maize. J. Appl. Bacteriol. 73, 375-387. doi: 10.1111/j.1365-2672.1992.tb04992.x

Muck, R. E. (2013). Recent advances in silage microbiology. Agric. Food Sci. 22, 3-15. doi: 10.23986/afsci.6718

Muck, R. E., Nadeau, E. M. G., McAllister, T. A., Contreras-Govea, F. E., Santos, M. C., and Kung, L. Jr. (2018). Silage review: recent advances and future uses of silage additives. J. Dairy Sci. 101, 3980-4000. doi: 10.3168/jds.201713839 
Páez, R., Lavari, L., Audero, G., Cuatrin, A., Zaritzky, N., Reinheimer, J., et al. (2013). Study of the effects of spray-drying on the functionality of probiotic lactobacilli. Int. J. Dairy Technol. 66, 155-161. doi: 10.1111/1471-0307.12038

Paéz, R., Lavari, L., Vinderola, G., Audero, G., Cuatrin, A., Zaritzky, N., et al. (2012). Effect of heat treatment and spray drying on lactobacilli viability and resistance to simulated gastrointestinal digestion. Food Res. Int. 48, 748-754. doi: 10.1016/j.foodres.2012.06.018

Peralta, G. H., Bergamini, C. V., Audero, G., Páez, R., Wolf, I. V., Perotti, M. C., et al. (2017). Spray-dried adjunct cultures of autochthonous non-starter lactic acid bacteria. Int. J. Food Microbiol. 255, 17-24. doi: 10.1016/j.ijfoodmicro.2017. 05.014

Reale, A., Di Renzo, T., Preziuso, M., Panfili, G., Cipriano, L., and Messia, M. C. (2019). Stabilization of sourdough starter by spray drying technique: new breadmaking perspective. LWT 99, 468-475. doi: 10.1016/j.lwt.2018.10.016

Reich, L. J., and Kung, L. Jr. (2010). Effects of combining Lactobacillus buchneri 40788 with various lactic acid bacteria on the fermentation and aerobic stability of corn silage. Anim. Feed Sci. Technol. 159, 105-109. doi: 10.1016/j.anifeedsci. 2010.06.002

Russo, P., Fares, C., Longo, A., Spano, G., and Capozzi, V. (2017). Lactobacillus plantarum with broad antifungal activity as a protective starter culture for bread production. Foods 6:110. doi: 10.3390/foods6120110

Sambrook, J., and Russell, D. W. (2001). Molecular Cloning: A Laboratory Manual, 3rd Edn. Cold Spring Harbor, NY: Cold Spring Harbor Laboratory Press.

Santos, A. O., Ávila, C. L. S., and Schwan, R. F. (2013). Selection of tropical lactic acid bacteria for enhancing the quality of maize silage. J. Dairy Sci. 96, 7777-7789. doi: 10.3168/jds.2013-6782

Sorrentino, E., Reale, A., Tremonte, P., Maiuro, L., Succi, M., Tipaldi, L., et al. (2013). Lactobacillus plantarum 29 inhibits Penicillium spp. involved in the spoilage of black truffles (Tuber aestivum). J. Food Sci. 78, M1188-M1194. doi: 10.1111/1750-3841.12171

Uang, S., Vignolles, M. L., Dong Chen, X., Le Loir, Y., Jan, G., Schuck, P., et al. (2017). Spray drying of probiotics and other food-grade bacteria: a review. Trends Food Sci. Technol. 63, 1-17. doi: 10.1016/j.tifs.2017. 02.007

Vénica, C. I., Perotti, M. C., and Bergamini, C. V. (2014). Organic acids profiles in lactose-hydrolyzed yogurt with different matrix composition. Dairy Sci. Technol. 94, 561-580. doi: 10.1007/s13594-014-0180-7

Vinderola, C. G., and Reinheimer, J. A. (1999). Culture media for the enumeration of Bifidobacterium bifidum and Lactobacillus acidophilus in the presence of yoghurt bacteria. Int. Dairy J. 9, 497-505. doi: 10.1016/S0958-6946(99) 00120-X

Zwietering, M. H., Jongenburger, I., Rombouts, F. M., and van 't Riet, K. (1990). Modeling of the bacterial growth curve. Appl. Environ. Microbiol. 56, 18751881 .

Conflict of Interest Statement: The authors declare that the research was conducted in the absence of any commercial or financial relationships that could be construed as a potential conflict of interest.

Copyright (C) 2018 Burns, Borgo, Binetti, Puntillo, Bergamini, Páez, Mazzoni, Reinheimer and Vinderola. This is an open-access article distributed under the terms of the Creative Commons Attribution License (CC BY). The use, distribution or reproduction in other forums is permitted, provided the original author(s) and the copyright owner(s) are credited and that the original publication in this journal is cited, in accordance with accepted academic practice. No use, distribution or reproduction is permitted which does not comply with these terms. 